\title{
Marginal Land-based Biomass Energy Production in Yellow River Delta
}

\section{Congwen $\mathrm{Wu}^{1,2, a}$, Xiaobing Chen $\mathrm{n}^{2,3, \mathrm{~b}^{*}}$, Yunpeng Sun ${ }^{4,2}$, Mingliang Jiang ${ }^{5,2}$, Kun Yan ${ }^{2,3}$, Lihua Zhang ${ }^{2,3}$}

\author{
${ }^{1}$ College of Life Science, Yantai University, Yantai, Shandong , China \\ ${ }^{2}$ Yantai Institute of Coastal Zone Research Chinese Academy of Scieces, Yantai, Shandong, China \\ ${ }^{3}$ Key Laboratory of Coastal Zone Environmental Processes, Yantai Institute of Coastal Zone \\ Research, Chinese Academy of Sciences, Yantai, Shandong, China \\ ${ }^{4}$ College of Geography and Planning of Ludong University, Yantai, Shandong , China \\ ${ }^{5}$ College of Environmental Science and Engineering, Chang'an University, Xi'an, Shanxi , China

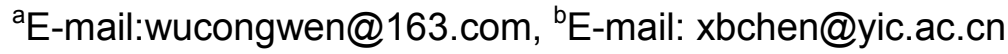

Keywords: Yellow River delta · Marginal land · Biomass energy · Energy crops · Saline

\begin{abstract}
Energy crops are not only the key to the development of biomass energy, but also can promote the improvement of saline and other marginal land and mprove the utilization efficiency. The rural biomass energy utilization status and characteristics of different energy crops and research status in Yellow River Delta was introduced; Castor, switchgrass and sweet sorghum grown in marginal land feasibility are discussed; Finally, the several suggestions of to promote biomass energy and local marginal land development have been proposed.
\end{abstract}

\section{Introduction}

Yellow River Delta is located in the south coast of Bohai bay and in the west coast of Laizhou bay, mainly in Dongying and Binzhou city, China. The total area of Yellow River Delta is about 1.75 million hectares, and there is 0.303 million hectares unused saline alkali soil in this area. . Marginal land resources in the Yellow River delta is rich, which accounts for as high as 70 percent or above of the saline alkali land[1]. Combined marginal land development and biomass energy meets the principle of "Can't compete with people for the grain, can't compete with grain for farmlad" and it help to promote the full development of marginal land.

Biomass is an emerging energy, which is based on organic wastes of agriculture and forestry and energy crops planted on marginal land[2]. Its characteristics are renewable and low pollution with widely distribution as an abundant rawmaterials. In China, the annual biomass power generation capacity reached 5.5 million kilowatts; bio-fuel ethanol production was 2 milion tons per annum; the rural household biogas utilization reached 19 billion cubic meters, about 500 million tons of standard coal equivalent[3,4]. It is reported that by 2020, 20 percent of U.S. transportation fuels would come from biofuels, and the same period China will reach $15 \%$, while Sweden would be close to $100 \%[5,6]$. The development and utilization of modern biomass energy technology has a very important significance for alleviating the energy crisis and environmental protection.

\section{Development Situations}

The utilization of rural biomass energy in Yellow River Delta Biomass energy in Yellow River Delta mainly includes rural biogas digesters and biogas engineering. In 2011, digester gas production of Dongying was 17,485,600 cubic meters and it was was 19,879,000 cubic meters in Binzhou, and the total valued was approximately $\$ 6,158,500[7]$. The utilization of rural biomass energy in Yellow River Deltain 2012 is shown in table 1. 
Table 1 The 2012 utilization of Yellow River Delta rural biomass energy

\begin{tabular}{cccc}
\hline Area & $\begin{array}{c}\text { Total biogas } \\
\text { production, }\left(\mathrm{km}^{3}\right)\end{array}$ & $\begin{array}{c}\text { Biogas Users, } \\
\text { thousand households }\end{array}$ & $\begin{array}{c}\text { Biogas projects } \\
\text { (Pool capacity above 300 } \\
\text { kilostere) }\end{array}$ \\
\hline Dongying & 1525.78 & 66.4 & 9 \\
Bingzhou & 2288.90 & 67.7 & 7 \\
Laizhou & 519.22 & 10.8 & 6 \\
Shouguang & 560.34 & 1.08 & 8 \\
Changyi & 777.78 & 1.58 & 3 \\
\hline
\end{tabular}

The use of crop straw and marginal land The main crops in Yellow River Delta are cotton, corn, rice, wheat and soybeans [8]. Cotton cultivation area is 333 thousand hectares, and annual yield of cotton stalks is about 1,875,000 tons. corn acreage is more than 286.7 thousand hectares, with annual output of corn stalks about 770 million tons[9]. The proportion of crop acreage of various types is illustrated in Figure 1. The residue to product ratio and the standard coal coefficient of different crops are shown in Table 2. According to the actual situation of cotton biomass in Yellow River Delta, the annual output value of marginal land in Dongying and Binzhou City is calculated (cotton yield of $1500 \mathrm{~kg}$ per hectare in this calculation, Table 3).

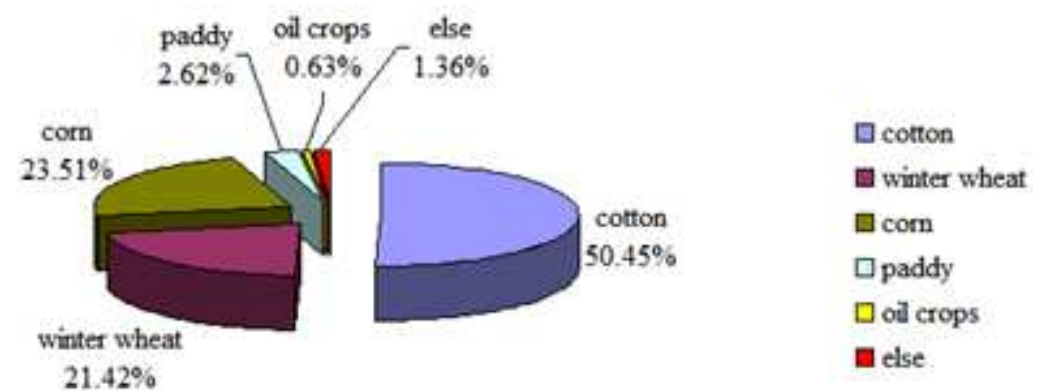

Fig.1 The proportion of various types of crop acreage in Dongying city[10]

Table 2 The residue to product ratio and the standard coal coefficient of different crops [11]

\begin{tabular}{cccccc}
\hline Items & Winter wheat & Paddy & Corn & Cotton & Oil crops \\
\hline RPR & 1.1 & 0.9 & 1.2 & 3.0 & 2.0 \\
SCC & 0.500 & 0.429 & 0.529 & 0.543 & 0.529 \\
\hline
\end{tabular}

Table 3 The theoretical annual output value of marginal land in Dongying and Binzhou City

\begin{tabular}{ccccc}
\hline Items & $\begin{array}{c}\text { Marginal land area, } \\
(\mathrm{ha})\end{array}$ & $\begin{array}{c}\text { Cotton yield } \\
(\mathrm{t})\end{array}$ & $\begin{array}{c}\text { Output of cotton stalks, } \\
(\mathrm{t})\end{array}$ & $\begin{array}{c}\text { Amount of standard } \\
\text { coal equivalent, }(\mathrm{t})\end{array}$ \\
\hline Dongying & 274,000 & 411,000 & 1130,250 & 565,100 \\
Binzhou & 120,667 & 181,000 & 497,750 & 249,000 \\
Total & 394,667 & 592,000 & 1628,000 & 814,100 \\
\hline
\end{tabular}

\section{Energy crops}

Research of energy crops has a crucial role for biomass energy scale and industrial development. In 1998, a book "Energy Plant Species"was published, and in this book, 16 kinds of "energy plants" such as sweet sorghum, cordgrass(Spartina spp.), Phragmites australis Trin and etc., were introduced [12]. 
Energy crops classification According to the material component of energy carrier, energy crops can be divided into 3 categories: (1) Starch and sugar crops, for the production of fuel ethanol; (2) Oil crops, used to generate biodiesel; (3)Lignocelluloses crops, converted into thermal energy, electricity, ethanol and biogas[12].

Starch and sugar crops The capacity to produce fuel ethanol are different in different crops, as shown in Table 4. Raw material for fuel ethanol in China is mainly corn and wheat aging, while corn in U.S and sugar cane in Brazil [13]. As shown in table 4, sugarcane, sugar beet and sweet sorghum have a strong fuel ethanol production capacity, which makes them as an important research goal in many countries. Sugarcane varieties of short growing season and high yield such as H69-9103, L79-1002, EMS145, EMS245 and etc. have been bred out in U.S. and Indian [14,15]. Chinese bred varieties of sugarcane as a fuel ethanol is Guifu 97-18. Recently, sweet sorghum varieties with high sugar content and strong resistance are Rio, Roma, Bailey, Cowley, BR-504, BXH34-3-1, and etc. However, dependence of fuel ethanol on food crops increased the contradiction between population growth and the food crisis.

Table 4 The starch and sugar crops and their ethanol productivity

\begin{tabular}{lcccc}
\hline crops & $\begin{array}{c}\text { Single yield } \\
\left(\mathrm{t} \cdot \mathrm{ha}^{-1}\right)\end{array}$ & $\begin{array}{c}\text { Sugar/starch } \\
\text { content }(\%)\end{array}$ & $\begin{array}{c}\text { Sugar/starch } \\
\text { production } \\
\left(\mathrm{t} \cdot \mathrm{ha}^{-1}\right)\end{array}$ & $\begin{array}{c}\text { Ethanol production } \\
\left(\mathrm{L} \cdot \mathrm{ha}^{-1}\right)\end{array}$ \\
\hline Zea mays & 6.9 & 65.0 & 4.49 & 2874 \\
Triticum aestivum & 7.2 & 62.0 & 4.46 & 2854 \\
Cichorium intybus & 35.0 & 16.0 & 5.60 & 3248 \\
Solanum tuberosum & 32.4 & 17.8 & 5.77 & 3693 \\
Saccharum officinarum & 80.0 & 10.0 & 8.00 & 5400 \\
Beta vulgaris & 57.4 & 16.0 & 9.18 & 5600 \\
Sorghum bicolor & 90 & 10.0 & 9.00 & 5400 \\
\hline
\end{tabular}

Oil crops Oil crops is herbs or woody plants and used for extracting the oil. The domestic energy plants were listed in table 5. Nowadays, ricinus communis, glycines max and brassia campestris have already achieved commercial cultivation to produce biodiesel. In order to meet the increasing demand of biodiesel, the oil crops research has been deepening. According to reports, growth in the Australian adult Cuban tree (also known as the diesel tree), about $25 \mathrm{~L}$ of fuel oil can be obtained from them per year. growth oil, each of China's Hainan Nan trees can annually produce $10 \mathrm{~L}-25 \mathrm{~L}$ biodiesel, one kind of Brazil fragrant gum trees a year, secrete $40 \mathrm{~kg} \sim 60 \mathrm{~kg}$ glue, which clean the glue not be treated may directly as oil use [16]. there are 1.05 million jatropha trees in Sichuan Province, China, and average seeds yield is $1.5 \mathrm{~kg}$ each plant.Seed kernel oil rate is $50.0 \% \sim 61.2 \%$, andthe annual production of jatropha oil is $2250 \sim 3000 \mathrm{~kg}$ per hectare $[17,18]$.

Table 5 Major oil crops and productivity [12]

\begin{tabular}{lccc}
\hline crops & grain yield $\left(\mathrm{t} \cdot \mathrm{ha}^{-1}\right)$ & oil length $(\%)$ & Oil production $\left(\mathrm{t} \cdot \mathrm{ha}^{-1}\right)$ \\
\hline Gossypium spp. & 1.20 & $15-25$ & 0.29 \\
Ricinus communis & 1.20 & 50.00 & 0.6 \\
Crambe abyssinica & $2.00-3.50$ & $30-45$ & 0.74 \\
Cocos nucifera & 4.17 & 36.00 & 1.50 \\
Elaeis guineensis & 30 & 26.00 & 7.80 \\
Helianthus annuus & $2.50-3.20$ & $35-52$ & $0.88-1.67$ \\
Arachis hypogaea & 2.00 & $45-53$ & 1.00 \\
\hline
\end{tabular}


Lignocellulosic crops Lignocellulosic crops can be used as the energy source of bio-ethanol, bio-gas, heating,power generation or generate electricity.Main lignocellulosic crops and their yields and energy balance are displayed in the table 6 .

Compared with traditional crops, lignocellulosic crops with better resistance and adaptability to marginal land are more suitable to be used for the development of marginal land. Researches showed that medicago at $0.3 \%$ salinity can still grew normally and each one kilogram of fresh medicago obtained 300 grams residue and 100 grams ethanol after crush [19,20]. Europe has bred the triploid giant miscanthus. This plant height is $7-10 \mathrm{~m}$, and theoretical yields is up to 22 tons per ha, while calorific value is $18.2 \mathrm{MJ}$ each kilogram.

Algae biofuels Algae are referred to as "the third generation biofuels" because ofthe production of biodiesel and algae hydrogen [21]. Microalgae was originally designed to stabilize atmospheric $\mathrm{CO}_{2}$ content and reduce global warming.

However, it received a lot of national attention because of its characteristics of non-toxic and non-sulfur, high productivity and benefits to the environment. It is estimated that in $2020,30 \%$ of the algae biofuel can be used to produce petroleum distillates, and the annual production of algae biofuels will increase to 6 billion gallons in 2025 [22]. Algae also can provide a wide range of valuable products, such as $\omega-3$ fatty acids, animal feed, energy resources, organic fertilizers, recombinant proteins, drugs and vaccines [23,24].

Table 6 The yield and capacity characteristics of major ligocellulosic crops [25]

\begin{tabular}{lcccc}
\hline crops & $\begin{array}{c}\text { yield of Fresh } \\
\text { weight, } \mathrm{t} \cdot \mathrm{ha}^{-1}\end{array}$ & $\begin{array}{c}\text { Share of dry } \\
\text { matter, } \%\end{array}$ & $\begin{array}{c}\text { energy content } \\
\mathrm{GJ} \cdot \mathrm{t}^{-1}\end{array}$ & $\begin{array}{c}\text { Energy outputs, } \\
\mathrm{GJ} \cdot \mathrm{ha}^{-1}\end{array}$ \\
\hline Sweet sorghum & $50-100$ & $23-35$ & $16.7-16.9$ & $250-422$ \\
Arundo donax & $45-110$ & $35-40$ & $16.5-17.4$ & $240-600$ \\
Miscanthus spp. & $40-70$ & $35-45$ & $17.6-17.7$ & $260-600$ \\
Panicum virgatum & $25-60$ & $35-45$ & 17.4 & $174-435$ \\
Hibiscus cannabinus & $70-100$ & $25-35$ & $15.5-16.3$ & $155-326$ \\
Cynara cardunculus & $25-35$ & $40-45$ & $15.5-16.8$ & $155-252$ \\
\hline
\end{tabular}

The discuss of planted feasibility of several energy crops on marginal land in Yellow River Delta Since the marginal land in Yellow River Delta has characteristics of low organic matter content, lack of soil nutrients and serious salinization, traditional agricultural production has been greatly hampered. Breeding salt-resistant, drought-resistant and well- adapted energy crops become new ideas for marginal land exploitation.

Studies showed that ricinus communis can normally grow at 0.4 percent salinity, and the low concentration of salt treatment was in favor of seed germination [26,27]. Experiments indicated that the average yield of ricinus communis of saline soil plots was up to 5.4 tons per hectare and soil desalination rate was 51.95 percent after planting ricinus communis for 3 years [28]. ricinus communis was considered as the most promising plants for soil remediation and biodiesel production., switchgrass has vigorous growth ability, developed root system, strong pest resistant and easy to harvest, and can well grow in poor soil and saline alkali area along with the salt tolerant threshold of $178.6 \mathrm{mmol} \cdot \mathrm{L}^{-1}$ [29]. Switchgrass biological yield was up to 20 tons per ha, the calorific value of dry basis of switchgrass per kilogram was approximately $14.5 \mathrm{MJ}$, which was equivalent to $70 \%-80 \%$ of the same quality coal[30]. Sweet sorghum is also called "second-generation sugarcane." The $\mathrm{NaCl}$ concentration range of sweet sorghum tolerance is $0 \sim 550 \mathrm{mmol} \cdot \mathrm{L}^{-1}$, and the salt tolerance is different in the varieties. BJ-18 is a strong salt tolerance variety [31]. China has a total of sweet sorghum resources in 374 place, of which 159 landraces copies and four pairs CMS lines and maintainers [32].Certainly, cultivation technology, transportation and policy are also crucial for marginal land development as well as for the breeding of good varieties. 


\section{Conclusions and future prospects}

Marginal land exploitation with biomass energy production has tremendous social, economic and ecological benefits. Research on energy crops is still in the initial phase, while transgenic approaches for increasing plant salt tolerance are demonstrated to be feasible. In order to reduce the dependence of energy crops on cultivated land, marginal land will become a hot issue of future development. The following points should be carried out for marginal land utilization and biomass energy development :(1) combining energy crop breeding with biotechnology; (2) combining government's policy with biological energy engineering; (3) combining large-scale cultivation with agricultural enterprise; (4) combining state subsidy with rural biogas.

\section{Acknowledgments}

The authors are grateful for the financial support of the Special Funds for Agro-scientific Research in the Public Interest of China (200903001) and Public science and technology research funds projects of ocean of China (201105020).

\section{References}

[1] Guan YX, Liu GH, Wang JF (2001) Regionalization of Salt-affected Land for Amelioration in the Yellow River Delta Based on GIS. Acta Geographica Sinica, 56(2):198-205(in Chinese)

[2] Wang O (2007) The utilization status and policy and future trends of bioenergy and biomass utilization in China. Chinese Rural Economy, 7:10-15(in Chinese)

[3] Wang LC, Liu Y, Du FG (2009) Actuality and prospect of biomass energy in China. Henan Chemicals Industry 9:15-19(in Chinese)

[4] Shen XL (2011) Impact factor in the development of biomass energy analysis. Journal of Southwest Petroleum University(Social Sciences Edition), 4(001):75-80(in Chinese)

[5] Xinhuanet (2011) The People's Republic of China the twelfth five-year plan for national biomass energy development program [DB/OL]. http:/www.china.com.cn/,2011-03-16 (in Chinese)

[6] Yu HL (2008) The problem of development of biomass energy in Heilongjiang province. Economic Research Guide, 03:114-117(in Chinese)

[7] Xiong FL, Zhu HG, Shi HR (2011) Analysis on the price of the biogas for rural centralized biogas plant. China Biogas, 29(4):16-19(in Chinese)

[8] Pan ZQ, Liu GH, Zhou CH (2003) The crop distribution of Yellow River Delta using remote sensing method. Geographical Research, 22(6):799-807(in Chinese)

[9] Wan TP, Qi Y (2013) Tianjin rural biogas biomass energy development overview. Renewable Energy Resources, 03:125-128(in Chinese)

[10] Statistical yearbook of shandong province in 2012[M]. Beijing: China statistics press(in Chinese)

[11] Li JJ, Ren DM, Zhuang X (2001) Systemic evaluation method of renewable energy resources and its practical application. Journal of Natural Resources, 16(4):373-380(in Chinese)

[12] Bassam NE.(1998) Energy Plant Species, Their use and impact on environment and development [M].James and James(SciencePublishers)Ltd.London

[13] Li J, Wu PZ, Li MR (2007) Development of Energy Plant: Progress and Suggestions. Chinese Journal of Nature, 01:21-25(in Chinese)

[14] Zhang H, Chen RK (2002) Research and development of our country's energy sugarcane. Sugacane, 04:33-35(in Chinese) 
[15] Fei SM, Zhang XD, Yang GY. (2005)On domestic and international situation of energy plant resources and their exploitation. Journal of Sichuan Forestry Science and Technology, 03:20-26(in Chinese)

[16] Li S, Yang PZ, Yang GY (2003) Practical significance of study the development of energy sugarcane production. Guangxi Sugarcane \& Canesugar, 03:44-45(in Chinese)

[17] Wu GJ, Liu J, Lou ZP (2006) Development of energy plant: Progress and suggestions, Bulletin of Chinese Academy of Sciences, 21(1):53-57(in Chinese)

[18] Fei SM, Chen XP, He YP (2006) Prospects of studies on jatropha curcas biodiesel in Sichuan. Biomass Chemical Engineering, 40:193-199(in Chinese)

[19] Cheng X (2013) Grasses as biofuel play a significant role for biomass energy in future. Acta Prataculturae Sinica, (1):27-29(in Chinese)

[20] Samac D A (2006) Development of alfalfa as a feedstock for production of ethanol and other bio-products[A]. Shelley Minteer, Alco-holic Fuel[M]. Taylor \& Francis

[21] Pande, M.,A.N. Bhaskarwar. (2012) Biomass conversion to energy, in Biomass Conversion[M].Springer Berlin Heidelberg.1-90

[22] Thurmond W (2012)Algae 2020: biofuels Markets, business models, strategies, players and commercialization outlook, 2012-2020

[23] Pulz, O.,W. Gross. (2004)Valuable products from biotechnology of microalgae. Applied Microbiology and Biotechnology, 65(6):635-648.

[24] Pienkos PT, Darzins A.(2009) The promise and challenges of micro-algal derived biofuel. Biofuel Bioproducts Biorefin.(3):431-440.

[25] Venturi P, Venturi G(2003) Analysis of energy comparison for crops in European agricultural systems. Biomass and Bioenergy, 25(3): 235 255.

[26] Yu CY (1985)Determination of Ricinus communis seedling emergence and seedling stage. Shandong Agricultural Sciences, 3:15-17(in Chinese)

[27] Wang JM, Ruan CJ, Huang MY (2011) Preliminary study of salt-tolerant of castor. Journal of Henan Agricultural Sciences, 40(5):67-73(in Chinese)

[28] Zhang HJ, Zhao HY (2010) Amelioration effects of ricinus communis to salinized soil. Soil and Water Conservation in China, (007):43-44(in Chinese)

[29] Li GY, Li JL, Wang Y (2008) Research progress on the clean bio-energy production from high yield Panicum virgatum. Pratacultural Science, 25(5):15-21(in Chinese)

[30] Fan XF, Hou XC, Zhu Y (2012) Impacts of salt stress on the growth and physiological characteristics of Panicum virgatum seedlings. Chinese Journal of Applied Ecology, 23(6):1476-1480(in Chinese)

[31] Cong QY, Zhang H, Yang GY (2011) Salt-tolerance in different varieties of Sweet sorghum seeding. Chinese Agricultural Science Bulletin, 26(19):128-135(in Chinese)

[32] Gao SJ, Liu XH, Li YF (2006) Sweet sorghum resources and its utilization in China. Rain Fed Crops, 26(4):273-274(in Chinese) 